\title{
The etiology of XX sex reversal
}

\author{
A de la Chapelle1, J Hästbacka1', T Korhonen2, J Mäenpää3 \\ ${ }^{1}$ Department of Medical Genetics, University of Helsinki, Haartmaninkatu 3, 00290 Helsinki; \\ 2 Department of Medicine, University of Kuopio; \\ ${ }^{3}$ Aurora Hospital, Helsinki, Finland
}

(28 Réunion de la Société Française pour l'Étude de la Fertilité; Paris, 19-21 octobre 1989)

Summary - The primary testis-determining function is exerted by a gene in the sex-determining region of the human $Y$ chromosome. This gene is termed the sex-determining factor or TDF. A zinc finger gene, $Z F Y$, residing in this region has been cloned and characterized. It is a candidate for TDF. A challenge to future molecular research is to clarify the function of a zinc finger gene on the $X$ chromosome, ZFX, that shows high structural similarity to ZFY. Furthermore, the existence of other genes involved in sex determination is likely but so far unproven.

Sex reversal leading to testes in apparently $X X$ individuals ( $X X$ males) is most often due to the presence of TDF on the paternally derived $X$ chromosome. The abnormality arises during meiosis in the father when an abnormal exchange leads to the transfer onto the $X$ of the entire pseudoautosomal region plus a portion of the $Y$ chromosome-specific region including TDF from the $Y$. An $X X$ male resulting from such an exchange is described.

$10-20 \%$ of $X X$ males do not have Y DNA. Two major mechanisms to explain such $Y(-) X X$ males are discussed. First, several published pedigrees show clear-cut dominant autosomal or $X$ chromosomal inheritance of $X X$ maleness. These patients are always $Y(-)$ and usually have sexual ambiguity. This indicates the existence of other genes, obviously 'downstream' from TDF, that when mutated can trigger testis determination. Nothing concrete is presently known about these putative genes, but their phenotypic effect is slightly different from that of TDF. Second, mosaicism with a prevalent $X X$ lineage and a hidden or scarce lineage containing a Y chromosome can explain some apparently $Y(-) X X$ males. Two $X X / X X Y$ mosaic patients are described in detail. In one, only a combination of DNA hybridization and cytogenetic studies led to the discovery of the XXY cell line. In conclusion, $\mathrm{XX}$ sex reversal in man is caused by at least 3 mechanisms, viz. abnormal $\mathrm{Y}-\mathrm{X}$ interchange, genes other than TDF, and mosaicism.

seX reversal / XX male / hermaphroditism / testis determination / $Y$ chromosome / $X$ chromosome / mosaicism

Résumé - Étlologie de l'inverslon du sexe chez les sujets XX. Dans l'espèce humaine, la détermination du sexe masculin est sous la responsabilité d'un yéne présent dans la région déterminant le sexe du chromosome Y. Un gène en "doigt de zinc", ZFY, localisé dans cette région a été cloné et caractérisé. C'est un candidat pour le TDF (testis-determining factor). Dans l'avenir, la recherche moléculaire devra élucider la fonction du gène en edoigt de zinc» du chromosome X, ZFX, qui présente une grande similitude de structure ZFY. Par ailleurs, l'existence d'autres gènes impliqués dans la détermination du sexe est probable mais non encore démontrée.

L'inversion du sexe entraînant la présence de testicules chez des individus $X X$ (hommes $X X$ ) est le plus souvent due à la présence de TDF sur le chromosome $X$ d'origine paternelle. L'anomalie se produit au cours de la méiose par échange anormal entre les chromosomes $X$ et $Y$ entrainant le transfert sur le chromosome $X$ de toute la région pseudoautosomale et d'une portion de la région spécifique du chromosome $Y$ et comprenant le TDF. Pour illustrer ceci, le cas d'un hormme XX résultant de cet échange est décrit.

Dix à vingt pour-cent des hommes $X X$ n'ont pas de DNA Y. Deux mécanismes principaux pour expliquer cette anomalie chez les hommes $X X Y(-)$ sont discutés. Tout d'abord, plusieurs généalo- 
gies publiées montrent clairement que la transmission héréditaire se fait selon le mode dominant soit autosomique soit lié au chromosome $X$. Ces patients sont toujours $Y(-)$ et ont, en général, une ambigüité sexuelle. Ceci indique l'existence d'autres gènes, évidemment «en avalı du TDF, qui ayant muté peuvent déterminer le sexe masculin. Rien de bien établi n'est actuellement connu concernant ces gènes mais leur effet sur le phénotype est légèrement différent de celui du TDF. Deuxièmement, le mosaïcisme avec une lignée XX prédominante et une lignée inapparente ou rare contenant un chromosome $Y$ peut expliquer quelques hommes $X X$ apparemment $Y(-)$. Deux patients présentant un mosaïcisme $X X X X X Y$ sont décrits en détail. Chez l'un, seule la combinaison de l'hybridation du DNA et des études cytogénétiques a permis la découverte de la lignée cellulaire XXY. En conclusion, l'inversion du sexe chez les individus $X X$ est due au moins à trois mécanismes : l'échange anormal entre $Y$ et $X$, la présence d'autres gènes que le TDF et enfin le mosaicisme.

Inversion du sexe / male XX / hermaphrodlsme / détermination du sexe / chromosome $Y$ / chromosome X/mosaicisme

\section{INTRODUCTION}

As a result of the advances in molecular genetics that have been made in the 1980 's, fairly detailed knowledge is now available about the location of the gene on the $Y$ chromosome that presumably induces the undifferentiated gonad to become a testis. To understand how testis determination operates, it is necessary to be familiar with the map of the pseudoautosomal and adjacent regions of the human $Y$ and $X$ chromosomes. This aspect is extensively discussed in the chapter by Weissenbach and Rouyer in this volume. In this paper, we shall briefly review the molecular aspects of primary sex determination, and thereafter attempt to summarize the present understanding of the etiology of $X X$ sex reversal in man, emphasizing the correlations that exist between clinical, molecular and cytogenetic data.

\section{A SEX-DETERMINING REGION ON THE HUMAN Y CHROMOSOME}

Testes form in individuals with a $Y$ chromosome (eg, karyotypes $X Y, X X Y, X Y Y$, $X X X Y, X X X X Y$ and mosaics with a $Y$ chromosome). Some 30 years ago, this fact led to the realization that there is a gene on the $Y$ chromosome that is critical and essential for testis determination. Before anything was known about the nature of this hypothetical gene, it was named testis determining factor (TDF). Subsequently, DNA probes isolated from the human $Y$ chromosome (Bishop et al, 1983) were used to construct a deletion map of the $Y$ chromosome based on findings in $X X$ males, $X Y$ males and males with a deletion of the $Y$ chromosome. These studies unequivocally placed TDF very distally on the short arm of the $Y$ chromosome (Vergnaud et al, 1986). A candidate gene for TDF was later cloned and characterized (Page et al, 1987a). The testis-determining region was defined as a DNA segment less than 200 kilobases (kb) long that was present in an $X X$ male with a minimal piece of $Y$ chromosome-derived DNA and absent in an $X Y$ female with a very small deletion. A phage chromosome walk of this region of the $Y$ chromosome disclosed the presence of a small number of areas showing extensive sequence conservation among not only all mammals tested, but even birds. These sequences were shown to contain an open reading frame that encodes a cys-cys and his-his zinc finger repeat. Thus, a prime candidate for TDF was cloned and partially characterized (Page et al, 1987a). While 
available evidence indicates that the zinc finger gene on the $Y$ chromosome may be $T D F$, final proof must await more direct evidence. In particular, it remains unclear what function, if any, should be ascribed to a gene on the $X$ chromosome that also encodes a zinc finger protein and is almost identical to the zinc finger protein gene on the $Y$ chromosome. These genes were subsequently named $Z F Y$ for zinc finger $Y$ and $Z F X$ for zinc finger $X$ (Page, 1988).

\section{$Y$ Y $X$ INTERCHANGE IN THE ETIOLOGY OF XX MALES}

Based on the abnormal inheritance of the blood group XG in some XX males (de la Chapelle et al, 1964), it was proposed that $X X$ maleness arose as a result of exchange between the $Y$ and $X$ chromosomes during the father's meiosis (Ferguson-Smith, 1966). As a result, TDF would become localized on the paternal $X$ chromosome, and induce testicular differentiation in an apparently $X X$ individual. The mapping and cloning of the distal part of the short arm of the human $Y$ chromosome provided the tools to show that $Y$ DNA indeed is present in most $X X$ males (Guellaen et al, 1984; Page et al, 1985). The interchange is illustrated below by an example.

\section{Clinical description}

LGL 1358, a 15 year old boy was referred for further examination because the school physician had noted gynecomastia and small testes. His parents were nonconsanguineous, aged 22 (father) and 25 (mother) at his birth. He had a normal younger sister. The patient's birth weight was $3160 \mathrm{~g}$. He had no remarkable medical history. School performance was above average. Records from the school health station showed that puberty began at 12 years; his final growth spurt occurred at 12.5-13 years of age.

Examination showed a healthy-appearing adolescent male. Height $167 \mathrm{~cm}$, weight $58 \mathrm{~kg}$ (father $182 \mathrm{~cm}$, mother 165 $\mathrm{cm})$. The epiphyses were almost closed (bone age 18 years). Testes small, $2.5 \mathrm{~cm}$ and soft. Penis somewhat smaller than normal. Virilization, including pubic and axillary hair entirely normal. Clear-cut bilateral gynecomastia with palpable glandular tissue. Serum testosterone $8.6 \mathrm{nmol} / \mathrm{l}$ (normal 14-33), luteinizing hormone $19 \mathrm{IU} / \mathrm{l}$ (normal upper limit 12), follicle stimulating hormone $30 \mathrm{IU} / \mathrm{I}$ (normal upper limit 12).

At follow-up in 1987 after 2 years' replacement therapy with testosterone, height was $169 \mathrm{~cm}$, weight $64 \mathrm{~kg}$, gynecomastia still existed but had diminished in size.

\section{Cytogenetics}

The karyotype was $X X$ in blood lymphocytes (100 metaphases studied) without signs of any cytogenetic abnormality.

\section{Molecular studies}

The patient's DNA was found to contain several $Y$ chromosomal DNA sequences, including ZFY. The molecular event leading to the abnormal genotype could be dissected in detail because the patient's parents and paternal grandparents were available for study. Thus, the coupling phase of informative pseudoautosomal restriction fragment length polymorphisms (RFLP) could be determined in the father. In other words, it could be determined which alleles were on the $Y$ chromosome, 
and which were on the $X$ chromosome in the father. Those studies have already been reported (Page et al, 1987b). Briefly, locus DXYS14 at the very end of the $X$ and $Y$ chromosomes, as well as an RFLP for the MIC2 gene close to TDF were informative. It could be shown that the patient had inherited the father's $Y$ chromosomal alleles of both loci and, in addition, the father's $X$ chromosomal allele for MIC2 but not DXYS14. The interpretation is that a crossover had led to the transfer of the entire pseudoautosomal segment (plus ZFY) from the father's $Y$ chromosome to the father's $X$ chromosome. Moreover, the break on the $X$ chromosome occurred more distally than on the $Y$ chromosome, thus allowing the MIC2 gene to be present in two copies on the aberrant recombinant paternal $X$ chromosome that the son (LGL 1358) inherited. This grossly unequal crossover is schematically depicted in fig 1.

When the sperm containing the abnormal recombinant $X$ chromosome fertilized the ovum with a normal $X$ chromosome, the resulting zygote became $X X$ male $L G L$ 1358.

In summary, the patient exhibited clinical signs and symptoms typical of $X X$ males: male habitus without obvious signs of abnormalities of any kind. There was no consanguinity or any family history of sex reversal. Cytogenetic analyses consistent- ly revealed only $46, X X$ and both $X$ chromosomes appeared structurally normal on $G$ banding. Molecularly, the paternal $X$ chromosome of the proband was rearranged as a result of an abnormal interchange between the $X$ and $Y$ chromosomes. The proband's paternal $X$ chromosome had acquired the entire pseudoautosomal region plus the sex-determining region from the $Y$ chromosome, so that it contained ZFY and possibly other $Y$ chromosome-specific genes.

The acquisition of TDF explains why the patient has testes. His clinical signs are typical of males with this abnormality. Of all males studied, $80-90 \%$ developed in this way (Page et al, 1985; Affara et al, 1986; de la Chapelle, 1986; Müller et al, 1986; Page, 1986; Seboun et al, 1986; Vergnaud et al, 1986).

\section{MALES WITHOUT ANY Y CHROMOSOMAL DNA}

The DNA from a majority of all $X X$ males studied have $Y$ chromosome-specific sequences including $Z F Y$. (It can be reasonably assumed that patients studied before $Z F Y$ was cloned and that were reported to have $Y$ chromosomal DNA, do in fact also have $Z F Y$.) Summarizing several large series of $X X$ males in which $Y$ DNA has been searched for, 59 out of a total of $86 \mathrm{XX}$

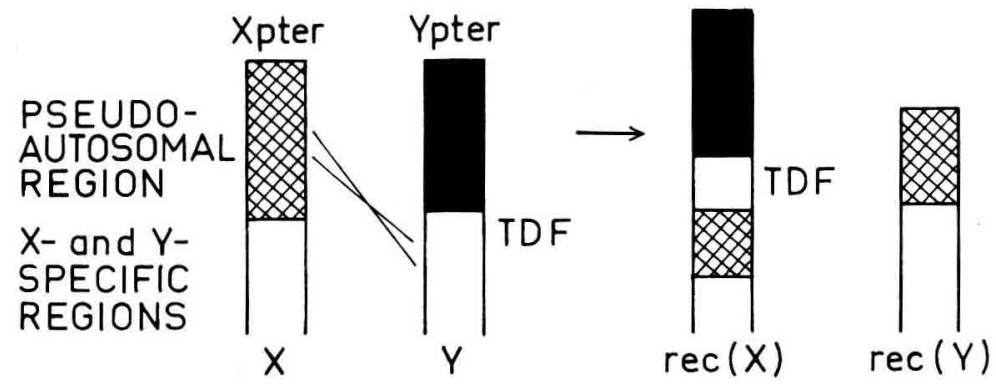

Fig 1. Schematic representation of the abnormal $X-Y$ interchange in the paternal meiosis leading to $\mathrm{XX}$ male LGL 1358. 
males $(69 \%)$ were reported to be positive for $Y$ chromosomal DNA (de la Chapelle, 1987). These patients will be referred to as $Y(+) X X$ males. It follows that in some $31 \%$ no $Y$ chromosome-specific DNA could be demonstrated. These will be referred to as $\mathrm{Y}(-) \mathrm{XX}$ males.

The etiology of maleness in most of these $Y(-) X X$ males is not yet understood. A small number of them can be explained as follows. At the time several of the studies were published, ZFY had not yet been cloned. The most distal markers on the $Y$ chromosome available to several of the research groups, including ours, was later shown to be proximal to ZFY. Thus, in occasional $X X$ males reported to be $Y(-)$, further studies with more distal $Y$ chromosomal probes have shown them to be $Y(+)$. Such is the case with, eg, XX male LGL 203 first believed to be $Y(-)$ (Vergnaud et al, 1986) but who later turned out to have a small piece of $Y$ DNA including ZFY (Page et al, 1987a). Presently, the proportion of $Y(-) X X$ males is estimated to be $10-20 \%$.

In the majority of $Y(-) X X$ males, there is no clue as to the etiology of sex reversal (de la Chapelle, 1988). Several hypotheses can be proposed. First, as the function of $Z F X$ is presently unknown, an abnormality of structure or expression of ZFX might lead to testis determination. Second, presently unknown $X$ chromosomal or autosomal genes might turn into testisdetermining genes through mutation or otherwise altered activity. Third, these patients might be low-grade mosaics having a $Y$ chromosome in only a small proportion of their cells.

\section{A role for ZFX ?}

An alteration in $Z F X$ leading to testis determination in $X X$ individuals cannot presently be ruled out. Once the function of ZFX under normal circumstances becomes under- stood, it should be easier to devise experiments to test for its abnormalities and their consequences.

According to one hypothesis, ZFX might encode a protein that is interchangeable with the $Z F Y$ product, and these might together determine the sex of the undifferentiated gonad as a function of their dosage (Page et al, 1987a). This hypothesis has been vigorously supported (German, 1988; Ferguson-Smith, 1988). A prerequisite for the hypothesis is that ZFX undergo inactivation when on an inactive $X$ (Page et al, 1987a). However, it has recently been shown that $Z F X$ escapes inactivation (Schneider-Gädicke et al, 1989). Moreover, a dosage-dependent mechanism of sex determination as a function of the sum of $Z F Y$ and $Z F X$ gene products does not tally well with the well-known high specificity of testis determination in the presence of a $Y$ chromosome, regardless of the number of $X$ chromosomes present (Schneider-Gädicke et al, 1989). Under such circumstances, the proposed dosagedependent abnormal sex differentiation in 2 rare females with a duplication in the region of $X p$, where ZFX is located, is not easily explained (Scherer et al, 1989). A direct, albeit inconclusive argument against a role of ZFX in the etiology of maleness in $Y(-) X X$ males is the fact that no structural abnormalities of ZFX have been detected by Southern blotting (de la Chapelle, unpublished results). Moreover, Northern hybridizations have shown $Z F X$ to be widely transcribed in many normal tissues and cell lines, without detectable alteration in several $Y(-) X X$ males studied by this method (Schneider-Gädicke et al, 1989; de la Chapelle, unpublished observations).

\section{Other sex-determining genes}

There is little doubt that genes other than zinc finger genes must play a role in the 
cascade of developmental events that take place in the undifferentiated gonad once the primary testis-determining signal has established the direction. Assuming that the primary signal is $Z F Y$, the other genes might be referred to as being 'downstream' from ZFY. As outlined by McLaren (1988), both 'loss-of-function' and 'gain-offunction' mutations could occur. In the latter case, dominant ( $X$ chromosomal or autosomal) inheritance might be expected in addition to sporadic occurrence.

Most XX males are sporadic (de la Chapelle, 1981). As reviewed recently, a few familial instances of $X X$ males have been described (de la Chapelle, 1987). These families are characterized by several potentially important features. First, like sporadic $Y(-) X X$ males, familially occurring $X X$ males have a high incidence of genital ambiguity or hypospadias, which are uncommon features in $\mathrm{Y}(+) \mathrm{XX}$ males. Second, in families with more than one case of $X X$ testicular differentiation, $X X$ males and $X X$ true hermaphrodites coexist, and appear to be examples of slightly different expressions of the same gene mutation. Thirdly, the pedigree pattern is usually compatible either with X-linked or autosomal-dominant inheritance, or both.

These findings suggest the existence of 'downstream, gain-of-function' genes that, when mutated, can lead to testicular differentiation in $X X$ individuals. Unfortunately, final proof of their existence must await further developments in our understanding of the details of sex determination mechanisms.

\section{MOSAICISM IN THE ETIOLOGY OF TESTICULAR DIFFERENTIATION IN THE APPARENT ABSENCE OF A Y CHROMOSOME}

Mosaicism presents no major diagnostic problem when it is readily detectable. For instance, in cases of Down's syndrome, cells with trisomy-21 and with a normal karyotype may coexist in many tissues. When both lines are present with appreciable frequency in blood lymphocytes, a phytohemagglutinin-stimulated culture of blood cells will yield metaphases of both types which can be recognized by a chromosome study. Mosaicism is thought to arise mainly as a postzygotic somatic event. For instance, in a zygote with trisomy-21, mosaicism involving a normal karyotype may arise as a result of difficulties of somatic pairing or segregation of all 3 chromosomes 21 with the occasional resulting loss of one. If the event takes place in an early zygotic division, both cell lineages may be widely distributed throughout most tissues and organs of the body.

As regards the $Y$ chromosome, 45, $X /$ $46, X Y$ mosaicism is relatively common, giving rise to what has been labeled 'mixed gonadal dysgenesis' (Sohval, 1963). Another example of $Y$ chromosome loss in somatic tissues comes from the bone marrow, where the $\mathrm{Y}$ chromosome is frequently lost from part or all of the cells in leukemia, especially in aged patients (Berger and Bernheim, 1979). $Y$ chromosomes that are structurally abnormal have a particularly strong tendency to get lost, as might be expected if the structural abnormality leads to difficulties in pairing. Especially when the abnormality involves the centromeric region, problems of segregation may easily occur. Many abnormal human $Y$ chromosomes have a symmetrical or semisymmetrical structure with 2 centromeres; they are often referred to as isodicentric $Y$ chromosomes (Magenis and Donlon, 1982).

For the purposes of this discussion, any male with a preponderant $46, X X$ cell line and another line comprising a normal $Y$ chromosome or an abnormal chromosome with $T D F$ is relevant. Do such mosaics exist? 


\section{$X X / X X Y$ mosaicism}

In a small proportion of patients with Klinefelter's syndrome $46, X X / 47, X X Y$ mosaicism has been described (reviewed in de la Chapelle, 1972). This type of mosaicism could well arise as a consequence of the early postzygotic loss of the $Y$ chromosome from a single cell of an XXY zygote, followed by continued propagation of both cell lineages. The bearer would have a high likelihood of being clinically abnormal, since $X X Y$ usually leads to Klinefelter's syndrome, and the XXY karyotype must be assumed to have been the primary one. Even if XXY were subject to negative selection, it would have a high probability of having been present at the time of onset of testicular differentiation in the gonadal primordium (at 5-6 weeks of gestation). Obviously, any karyotype of the zygote having two $X$ chromosomes plus an abnormal $Y$ chromosome would have the same (or higher) likelihood of producing mosaicism with an $X X$ line. If TDF were present on the abnormal $Y$ chromosome, testes would probably be induced.

To illustrate mosaicism of the type alluded to above, two examples will be given.

\section{Clinical description}

LGL 2882, a 34 year old carpenter sought medical advice in 1979 for gynecomastia.
His parents were non-consanguineous, aged 34 (father) and 31 (mother) at his birth. He had 4 normal siblings. He had no remarkable medical history. He considered his libido normal, but had remained unmarried. During the last 5 years, his weight had increased by more than $20 \mathrm{~kg}$ and gynecomastia had developed. Height 182 $\mathrm{cm}$, arm span $186 \mathrm{~cm}$, weight $103 \mathrm{~kg}$. Clear-cut bilateral gynecomastia with palpable glandular tissue. Testes small, $3 \mathrm{~cm}$, soft. Penis somewhat smaller than normal. Pubic hair sparse, axillary hair normal. Beard sparse; shaved 2-3 times per week. Serum testosterone $5.6 \mathrm{nmol} / \mathrm{l}$ (normal 1433). Serum luteinizing hormone 16.9 IU/I (normal upper limit in males 14). Prolactin $3.9 \mu \mathrm{g} / \mathrm{l}$ (normal). Bilateral mastectomy was performed with a good cosmetic result.

\section{Cytogenetics}

The patient could immediately be diagnosed as a $46, X X / 47, X X Y$ mosaic. As seen in Table I, phytohemagglutininstimulated cultures of blood cells and cultured fibroblasts readily showed the presence of both cell lineages. However, the $X X$ cells clearly predominated in both tissues $(79$ and $94 \%$, respectively). The $Y$ chromosome appeared structurally entirely normal.

Table I. Cytogenetic findings in two males with $46, X X / 47, X X Y$ mosaicism.

\begin{tabular}{llcccc}
\hline \multirow{2}{*}{$\begin{array}{l}\text { Patient } \\
\text { no }\end{array}$} & Tissue & \multicolumn{3}{c}{ No of metaphases } & $\begin{array}{c}\% \\
\text { metaphases } \\
\text { with 46,XX }\end{array}$ \\
\cline { 3 - 5 } & & $46, X X$ & $47, X X Y$ & total & \\
\hline \multirow{2}{*}{ LGL 2882 } & blood & 79 & 21 & 100 & 79 \\
& fibroblasts & 16 & 1 & 17 & 94 \\
LGL 2937 & blood (1986) & 20 & 0 & 20 & 100 \\
& blood (1989) & 89 & 11 & 100 & 89 \\
& fibroblasts (1989) & 29 & 79 & 108 & 27 \\
\hline
\end{tabular}




\section{Clinical description}

LGL 2937, a 53 year old farmer first sought medical advice in the 1960's for childlessness. His parents were nonconsanguineous, aged 36 (father) and 34 (mother) at his birth. He had 3 brothers who all had children. He was shorter than his brothers.

Azoospermia was diagnosed in the 1960's. In 1971, excision of left-sided gynecomastia was performed. In 1986, the findings were: height $160 \mathrm{~cm}$, weight 51 $\mathrm{kg}$. Left breast excised, right normal. Testes small, $2.5 \mathrm{~cm}$, soft. Penis normal. Facial, axillary and pubic hair normal. Serum testosterone $26.6 \mathrm{nmol} / \mathrm{l}$ (normal). Serum follicle stimulating hormone $46.0 \mathrm{IU} / \mathrm{I}$, luteinizing hormone $35.2 \mathrm{IU} / \mathrm{l}$ (both elevated).

\section{Cytogenetics}

A first phytohemagglutinin-stimulated blood cell culture in 1986 yielded only $46, X X$ cells and a preliminary diagnosis of $X X$ male syndrome was made. On this occasion, only 20 metaphases were studied and the fixed cells and slides were inadvertently lost so that more cells could not be studied from this sample. Subsequent- ly, DNA was extracted from a second blood sample in 1987 and included in a group of $X X$ males and $X Y$ females that were studied with a panel of $Y$ chromosome-specific probes, including $Z F Y$, to determine the presence or absence of $X-Y$ interchange or deletion of the $Y$ chromosome. With pDP97, a faint $Y$ chromosomespecific band was seen after EcoRIdigestion of a DNA sample from LGL 2937. These findings prompted a further search for cytogenetic evidence of a $Y$ chromosome. Cultures of phytohemagglutininstimulated blood lymphocytes and of skin fibroblasts established in 1989 yielded abundant mitoses. As can be seen in Table I, the predominant karyotype ( $89 \%$ of metaphases) was $X X$ in blood. This explains why none of the 20 metaphases examined in 1986 were $X X Y$. Of note is the pronounced difference in frequency of the two lineages between blood and fibroblasts. In the latter, XX cells were only $27 \%$.

\section{Molecular studies}

DNA hybridization using $Y$ chromosomespecific markers was performed on a DNA sample extracted from a culture of fibroblasts from LGL 2882 and whole blood

Table II. Southern DNA hybridization using $Y$ chromosome-derived probes on genomic DNA from two $X X / X X Y$ mosaic patients.

\begin{tabular}{|c|c|c|c|c|c|}
\hline \multirow[t]{2}{*}{ Locus } & \multirow[t]{2}{*}{$\begin{array}{l}\text { Probe/ } \\
\text { fragment }\end{array}$} & \multirow[t]{2}{*}{$\begin{array}{l}\text { Probe } \\
\text { reference }\end{array}$} & \multirow[t]{2}{*}{ Enzyme } & \multicolumn{2}{|c|}{$\begin{array}{c}\text { Presence of hybridization } \\
\text { with Y chromosome- } \\
\text { specific fragment }\end{array}$} \\
\hline & & & & LGL 2882 & LGL 2937 \\
\hline $\begin{array}{l}Z F Y \\
D Y S 7 \\
D Y Z 4 \\
D Y Z 3 \\
D Y S 7 \\
D Y S 7 \\
D Y Z 4 \\
D Y Z 1\end{array}$ & $\begin{array}{l}\text { pDP1007 } \\
50 f 2 / A, B \\
\text { pDP105/A } \\
\text { pDP97 } \\
5012 / D \\
50 f 2 / C, E \\
\text { pDP105/B } \\
\text { pY431-HinfA }\end{array}$ & $\begin{array}{l}\text { Page et al (1987a) } \\
\text { Guellaen et al (1984) } \\
\text { DC Page, unpublished } \\
\text { Wolfe et al (1985) } \\
\text { Guellaen et al (1984) } \\
\text { Guellaen et al (1984) } \\
\text { DC Page, unpublished } \\
\text { K Smith, unpublished }\end{array}$ & $\begin{array}{l}\text { EcoRI } \\
\text { EcoRI } \\
\text { Taql } \\
\text { EcoRI } \\
\text { EcoRI } \\
\text { EcoRI } \\
\text { Taql } \\
\text { HaellI }\end{array}$ & $\begin{array}{l}+ \\
+ \\
+ \\
+ \\
+ \\
+ \\
+\end{array}$ & $\begin{array}{l}+ \\
+ \\
+ \\
+ \\
+ \\
+ \\
+ \\
+\end{array}$ \\
\hline
\end{tabular}


from LGL 2937. The results are shown in table II. All probes showed a hybridization signal in both patients. As the probes represent 6 map intervals representing both the short and long arms of the $Y$ chromosome, it can be concluded that the entire $Y$ chromosome very likely was present in both patients. This is of course corroborat-

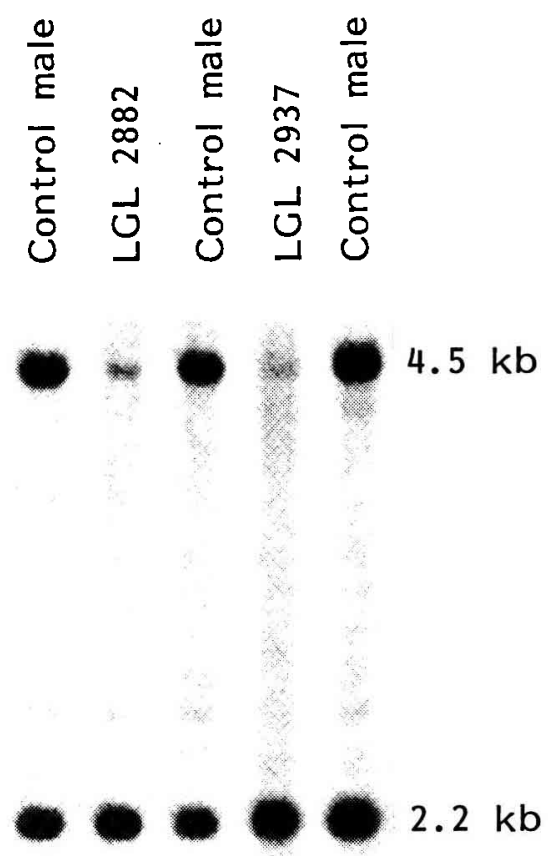

Fig 2. Southern hybridization of DNA from 3 control males and $2 X X / X X Y$ mosaic males. Genomic DNA was digested with EcoRI, electrophoresed, blotted onto a nitrocellulose filter and hybridized with probe 50f2. The larger $4.5 \mathrm{~kb}$ fragment emanates from the $Y$ chromosome, the smaller $2.2 \mathrm{~kb}$ fragment is from an unidentified autosome. The intensity of hybridization of the $2.2 \mathrm{~kb}$ autosomal fragment serves to compare the amounts of DNA in the different lanes. Thus LGL 2882 contains slightly more DNA than the adjacent controls. The LGL 2937 lane and the control lane on the right were deliberately overloaded. Note the weak $Y$ chromosomal signal of LGL 2882 and the even weaker signal of LGL 2937. ed by the fact that both $Y$ chromosomes were observed to be cytogenetically normal by banding methods. Fig 2 demonstrates the effect of the diminished $Y$ chromosome dosage on hybridization signal strength.

The two examples of $46, X X / 47, X X Y$ mosaicism described above indicate how the proportion of cell lineages can vary among tissues. Furthermore patient LGL 2937 illustrates the need to study more than one tissue, to examine a sufficient number of metaphases by cytogenetics and the value of Southern blotting in the search for lowgrade mosaicism involving the $Y$ chromosome. Probe pDP97, which under the appropriate stringency conditions detects $Y$ chromosome-specific alphoid repeat sequences (DYZ3) (Wolfe et al, 1985), is particularly useful for several reasons: 1) since the alphoid sequence is highly repeated in the $Y$ chromosome, the sensitivity relative to single-copy sequences is greatly enhanced; 2) while other probes detecting highly repeated sequences on the $Y$ chromosome, such as loci DYZ1 and $D Y Z 2$, exist, these sequences occur mostly or exclusively in Yq12, which is highly polymorphic and can even be absent in normal males; moreover, in many structurally abnormal $Y$ chromosomes, this region is absent; 3) since the alphoid repeat detected by pDP97 is close to the centromere, the chance that it is present in structurally abnormal $Y$ chromosomes is high.

\section{Clinical features}

Clinically, both mosaic males described had the characteristics of Klinefelter's syndrome. This is in keeping with expectations, since $47, X X Y$ was likely to have been the primary karyotype. The situation might be different in 46,XY/47, XXY mosajcism, which has been reported in occasional individuals with Klinefelter's syndrome and a mild disease, including spermatogenesis. 
CAN MOST EXAMPLES OF APPARENTLY Y(-) XX MALES BE EXPLAINED BY MOSAICISM ?

This question cannot be answered with certainty. The above examples illustrate the possibility that at least some patients exist in whom the $Y$ chromosomecontaining cell lineage is quite rare and occurs with variable frequency in different tissues. One is entitled to assume that the variation is due to selection either by chance or by the effect of unknown selective forces. Furthermore, in tissues necessitating long-term or short-term culture in vitro before they can be studied (eg, chromosome studies of fibroblasts or lymphoblasts) selection may occur in vitro. While direct evidence of selection relative to the $Y$ chromosome has not been presented in normal tissue, preferential loss of the $Y$ chromosome has been observed in several types of malignant tissue, eg, acute and chronic leukemias with or without a clonal chromosome aberration (Berger and Bernheim, 1979), leukemic cells with $t(8 ; 21)$ characteristic of acute myeloid leukemia (Second International Workshop on Chromosomes in Leukemia, 1980), and testis cancer (Peltomäki et al, 1989). A striking example of selection against an abnormal karyotype is provided by the PallisterKillian syndrome, in which a cell lineage with an $i(12 p)$ is often or always present but only in fibroblasts. In a recent study, it could be shown that even in fibroblasts, the abnormal clone was rapidly eliminated during in vitro culture (Peltomäki et al, 1987).

In conclusion, apparently $Y(-) \quad X X$ males in whom no other cell lineage is apparent or easily observable by conventional methods do exist, and at least some of them are mosaics. The virtual certainty that rare 'downstream' gene mutations can cause heritable $X X$ maleness (see above) argues in favor of such genes being responsible for some sporadic $Y(-) \quad X X$ males as well. Thus $Y(-) X X$ maleness very likely can be caused both by mosaicism, by gene mutations and perhaps by other mechanisms.

\section{ACKNOWLEDGMENTS}

This study was supported by grants from the Academy of Finland, the Sigrid Jusélius Foundation, and the Folkhälsan Institute of Genetics. We thank the scientists cited in table II for probes.

\section{REFERENCES}

Affara NA, Ferguson-Smith MA, Tolmie J, Kwok K, Mitchell M, Jamieson D, Cooke A, Florentin L (1986) Variable transfer of Y-specific sequences in XX males. Nucleic Acids Res 14, 5375-5387

Berger R, Bernheim A (1979) Y chromosome loss in leukemias. Cancer Genet Cytogenet 1, 1-8

Bishop CE, Guellaen G, Geldwerth D, Voss R, Fellous M, Weissenbach J (1983) Singlecopy DNA sequences specific for the human $\mathrm{Y}$ chromosome. Nature 303, 831-832

de la Chapelle A (1972) Analytic review: nature and origin of males with XX sex chromosomes. Am J Hum Genet 24, 71-105

de la Chapelle A (1981) The etiology of maleness in XX men. Hum Genet 58, 105-116

de la Chapelle A (1986) Genetic and molecular studies on $46, X X$ and $45, X$ males. Cold Spring Harbor Symp Quant Biol 51, 249-255

de la Chapelle A (1987) The $Y$ chromosomal and autosomal testis-determining genes. $\mathrm{De}$ velopment 101 suppl, 33-38

de la Chapelle A (1988) The complicated issue of human sex determination. Am J Hum Genet 43, 1-3

de la Chapelie $A$, Hortling $H$, Niemi $M$, Wennström J (1964) XX sex chromosomes in a human male. First case. Acta Med Scand suppl 412, 25-38

Ferguson-Smith MA (1966) X-Y chromosomal interchange in the aetiology of true hermaph- 
roditism and of $X X$ Klinefelter's syndrome. Lancet ii, 475-476

Ferguson-Smith MA (1988) Genes on the $X$ and $\mathrm{Y}$ chromosomes controlling sex. $\mathrm{Br}$ Med $J$ 297, 635-636

German J (1988) Gonadal dimorphism explained as a dosage effect of a locus on the sex chromosomes, the gonad-differentiation locus (GDL). Am J Hum Genet 42, 414-421

Guellaen G, Casanova M, Bishop C, Geldwerth D, Audre $G$, Fellous $M$, Weissenbach $J$ (1984) Human XX males with $Y$ single-copy DNA fragments. Nature 307, 172-173

Magenis E, Donlon T (1982) Non-fluorescent $Y$ chromosomes. Cytologic evidence of origin. Hum Genet 60, 133-138

McLaren A (1988) Sex determination in mammals. Trends Genet 4, 153-157

Müller U, Donlon T, Schmid M, Fitch N, Richer CL, Lalande M, Latt SA (1986) Deletion mapping of the testis-determining locus with DNA probes in 46,XX males and in 46, $X Y$ and $46, X, \operatorname{dic}(Y)$ females. Nucleic Acids Res 14, 6489-6505

Page DC (1986) Sex reversal: deletion mapping the male-determining function of the human Y chromosome. Cold Spring Harbor Symp Quant Bio/51, 229-235

Page DC (1988) Is ZFY the sex-determining gene on the human $Y$ chromosome? Philos Trans $R$ Soc London B 322, 155-157

Page D, de la Chapelle A, Weissenbach $J$ (1985) Chromosome $Y$-specific DNA in related human XX males. Nature 315, 224-226

Page DC, Mosher R, Simpson EM, Fisher E, Mardon G, Pollack J, McGillivray B, de la Chapelle A, Brown LG (1987a) The sexdetermining region of the human $Y$ chromosome encodes a finger protein. Cell 51, 1091-1104

Page DC, Brown LG, de la Chapelle A (1987b) Exchange of terminal portions of $X$ - and $Y$ chromosomal short arms in human $X X$ males. Nature 328, 437-440
Peltomäki P, Knuutila S, Ritvanen A, Kaitila I, de la Chapelle A (1987) Pallister-Killian syndrome: cytogenetic and molecular studies. Clin Genet 31, 399-405

Peltomäki P, Halme A, de la Chapelle A (1989) Molecular studies of the sex chromosomes in human testicular cancer: pronounced changes in $X$ and $Y$ chromosome dosage in some tumors. Genes Chromosomes Cancer 1, 4247

Scherer G, Schempp W, Bacchichetti C, Lenzini E, Bricarelli FD, Carbone LDL, Wolf U (1989) Duplication of an $X p$ segment that includes the $Z F X$ locus causes sex inversion in man. Hum Genet 81, 291-294

Schneider-Gädicke A, Beer-Romero M, Brown LG, Nussbaum R, Page DC (1989) ZFX has a gene structure similar to $Z F Y$, the putative human sex determinant, and escapes inactivation. Cell 57, 1247-1258

Seboun E, Leroy $P$, Casanova M, Magenis E, Boucekkine C, Disteche C, Bishop C, Fellous $M$ (1986) A molecular approach to the study of the human $Y$ chromosome and anomalies of sex determination in man. Cold Spring Harbor Symp Quant Biol 51, 237-248

Second International Workshop on Chromosomes in Leukemia, 1979 (1980) Morphological anaiysis of acute promyelocytic leukemia (M3) and $t(8 ; 21)$. Cancer Genet Cytogenet 2, 97-98

Sohval AR (1963) "Mixed" gonadal dysgenesis: a variety of hermaphroditism. Am J Hum Genet 15, 155-158

Vergnaud G, Page DC, Simmler MC, Brown L, Rouyer F, Noel B, Botstein D, de la Chapelle $A$, Weissenbach $J$ (1986) A deletion map of the human $Y$ chromosome based on DNA hybridization. Am J Hum Genet 38, 109-124

Wolfe J, Darling S, Erickson RP, Craig IW, Buckle VJ, Rigby PWJ, Willard HF, Goodfellow PN (1985) Isolation and characterization of an alphoid centromeric repeat family from the human $Y$ chromosome. $J$ Mol Biol 182, 477-485 